\title{
Celebrity gossip as a genre in English-language mass media discourse
}

\author{
Svetlana V. Ivanova ${ }^{1}$ and Gulnara Khakimova ${ }^{2}$ \\ ${ }^{1}$ Pushkin Leningrad State University \\ Saint-Petersburg, Russia \\ ${ }^{2}$ South Ural State University Branch in Zlatoust \\ Zlatoust, Russia
}

\begin{abstract}
The multidimensionality of rumours as part and parcel of mass communication has stipulated the research in their linguistic nature. The present paper studies this specific communication phenomenon and the discursive practices by means of which it is realized across the Anglophone mass media discourse continuum. The theory of discourse-analysis underpinning the present paper predetermines an integrative approach with various methods employed. This approach makes it possible to gain an insight into the complex nature of the object under study. The research is targeted at media rumours, namely celebrity gossip, manifested in on-line versions of the printed press and original web outlets in 2015-2018. The main goal of the research is to reveal specific features of media rumors as a speech genre in the Anglophone media communication. Celebrity gossip texts make up the empiric material for the present study. This aim is achieved via the description of the content and form of the text-type structure supplemented by an application of stylistic analysis. In terms of the topics, the findings demonstrate a wide variety of topoi comprising both public (social interactions) and private spheres of celebrities' life with an emphasis on privacy, sensationalism and scandalous impropriety as dominant discursive characteristics of the text-type samples under study. The structure of the celebrity gossip discourse is represented by texts in different journalistic forms: from informative genres to feature type variations used by authors as means of constructing celebrity culture. The information of trivial content and questionable validity because of its unverified character is disguised as reports of high testimonial trustworthiness and epistemic value with the help of a variety of language and textual resources. The results of the study enable us to argue that within the mass media communication there exists a specific discourse which is hybrid by nature and non-evidential by verification.
\end{abstract}

Keywords: media linguistics, mass media discourse, media rumours, celebrity gossip, text, genre

\section{For citation:}

Ivanova, Svetlana V. and Gulnara Khakimova. 2020. Celebrity gossip as a genre in Englishlanguage mass media discourse. Russian Journal of Linguistics 24 (2). 386-418. DOI: $10.22363 / 2687-0088-2020-24-2-386-418$ 
Научная статья

\title{
Жанр светских слухов в дискурсе англоязычных массмедиа
}

\author{
С.В. Иванова ${ }^{1}$, Г.Ш. Хакимова ${ }^{2}$ \\ ${ }^{1}$ Ленинградский государственный университет им. А.С. Пушкина \\ Санкт-Петербург, Россия \\ ${ }^{2}$ Филиал Южно-Уральского государственного университета в г. Златоусте \\ Златоуст, Россия
}

\begin{abstract}
Аннотация
Многомерность слухов как неотъемлемого элемента системы массовой коммуникации обусловила необходимость осмысления их лингвистической природы. Настоящая статья посвящена исследованию данного коммуникативного феномена и тех дискурсивных практик, которые реализуют его в континууме англоязычного массмедийного дискурса. Обращение к теории дискурс-анализа в качестве методологической основы в данной работе обусловливает интеграцию подходов и привлечение различных методов к изучению исследуемого конструкта, что обеспечивает возможность проникновения в его сложную природу. Объектом исследования избраны медиаслухи категории celebrity gossip (светские слухи), размещенные в электронных версиях англоязычных периодических изданий (газет и журналов) и оригинальных сетевых изданиях в 2015-2018 годах. Цель настоящего исследования заключается в выявлении специфики медиаслухов как речевого жанра англоязычной медиакоммуникации на примере текстов-слухов о селебрити. Указанная цель реализуется посредством выявления содержательного (тематического) и формального (структурно-композиционного) уровней архитектоники исследуемого текстотипа с привлечением стилистического компонента. В результате установлено, что тематический план медийных текстов-слухов о селебрити отличается широким диапазоном топосов, охватывающих как публичную сферу (социальные взаимодействия), так и приватную, зачастую интимную область жизни знаменитостей, с явным акцентом на последней. При этом сенсационность и скандальность оказываются доминантными дискурсивными характеристиками репрезентаций исследуемого текстотипа. В плоскости формального устройства дискурс светских слухов конституируется текстами, облеченными в различные журналистские формы: от жанров информационного блока до публицистических вариаций категории features, которые используются авторами в качестве средства конструирования реальности, связанной с культурой селебрити. Информация, имеющая, по сути, тривиальный по содержанию и сомнительный в силу своей неподтвержденности характер, с помощью разнообразных языковых и текстовых ресурсов камуфлируется под сведения, обладающие высокой степенью достоверности и эпистемической ценности. Полученные результаты свидетельствуют о существовании в рамках обширного коммуникативного пространства массмедиа специфического типа дискурса, гибридного по своей природе и неэвидентного в верификативном плане.
\end{abstract}

Ключевые слова: медиалингвистика, массмедийный дискурс, медиаслухи, светские слухи, текст, жанр

\section{Для цитирования:}

Иванова С.В., Хакимова Г.Ш. Жанр светских слухов в дискурсе англоязычных массмедиа // Russian Journal of Linguistics. 2020. Т. 24. № 2. С. 386-418. DOI: 10.22363/26870088-2020-24-2-386-418 


\section{1. Введение}

Данная работа посвящена исследованию природы своеобразного феномена - слухов - с позиций языковой практики. Научный потенциал лингвистики лишь только начинает привлекаться к его осмыслению. По оценкам специалистов, способ коммуникации, сопровождающий человечество с древнейших времен, переживает в настоящее время свое «второе рождение». Перестройка коммуникативных систем современного информационного общества, и, прежде всего, бурное развитие глобальной сети и компьютерных технологий, медиаконвергенция, обусловившая технологическую и культурную интеграцию коммуникационных и информационных технологий (старых и новых медиа), повлекшую за собой перераспределение ролей традиционных СМИ, привели к качественному изменению свойств слухов. Очевидным является тот факт, что слухи оказались весьма живучей и устойчивой формой передачи информации, способной успешно адаптироваться к новым условиям системы массовой коммуникации, мутируя и изменяя свои качественные характеристики (Куликов 2011, 2014). Парадоксально, но в рамках социальной психологии всё чаще звучит мнение о том, что с дальнейшим усилением институционализации общества индивидам будет сложнее получить жизненно важную для них информацию, в связи с чем информационная роль «слухового» канала будет лишь возрастать (Demerath and Korotayev 2015). Вслед за социологами представители философского направления, также указывая на усиливающуюся роль слухов в социуме, объясняют эту тенденцию валидностью слухов как источника информации, причем единственного в условиях продолжающейся институционализации, сопровождающейся все большим отчуждением от рядовых граждан значимой для них информации институтами власти (Gelfert 2012). Данные соображения обусловливают необходимость продолжения исследований в этой области в рамках различных подходов, включая лингвистическую парадигму, с целью системного описания категориальных признаков слухов, а также выявления новых свойств этого «мутирующего» феномена, что и позволяет аргументировать актуальность данной работы.

Объектом настоящей статьи являются такие конституэнты коммуникативного пространства, весьма типичные для современной англоязычной прессы, как медиаслухи категории celebrity gossip. Поскольку лингвистическая основа феномена слухов может быть выявлена в том числе с помощью описания текстовых репрезентантов, относящихся к избранному для анализа жанру медиатекстов, в качестве предмета исследования обозначены жанроводискурсивные характеристики текстов-слухов о селебрити в англоязычных массмедийных дискурсивных практиках. Соответственно, целью предпринятого исследования ставится выявление специфики медиаслухов как речевого жанра англоязычной прессы посредством конструирования прототипической модели слухов на примере текстотипа celebrity gossip в рамках англоязычной медиакоммуникации. Для её решения представляется необходимым осветить 
ряд вопросов: (1). Какой спектр тем (топиков) охватывают англоязычные тексты-слухи о селебрити? (2). Каков диапазон интенций создателей подобных текстовых экземпляров? (3). Каковы функции репрезентантов жанра cвеmские слухи в системе англоязычного массмедийного контента и какая функция является доминирующей? (4). Какой арсенал журналистских форм задействован при конструировании слухов о селебрити? (5). Каковы структурно-композиционные особенности репрезентаций исследуемого текстотипа? (6) Проявляет ли медиаслуховой дискурс признаки диффузности и конвергенции? (7) Наконец, каковы инвариантные и вариативные жанрово-стилевые признаки англоязычных текстов-слухов, подпадающих под категорию светских слухов?

Эмпирическим материалом предпринятого исследования послужили около 300 публикаций, представляющих собой медиаслухи рубрики gossip column или celebrity-gossip (ср.: светская хроника, колонка слухов, светские сплетни), размещенных в электронных версиях англоязычных периодических изданий (газет и журналов) и в англоязычных веб-изданиях в период с 2015 по 2018 годы. Настоящий выбор оправдан тем фактом, что репрезентанты данного текстотипа выступают как слухи per se, т.е. слухи в наиболее «чистом» виде.

Методологической основой данной работы послужил дискурсивно-ориентированный подход. Поскольку «в пределах своих границ он [дискурс-анализ] включает в себя разнородные подходы, аналитические инструменты и методологии, <..> объединяет различные научные школы» [Понтон, Ларина 2017: 18], в настоящем исследовании соединяются теоретические положения отечественной лингвистики текста, генристики, жанроведения и дискурсологии, воплощающие совокупность собственно языкового, лингвопрагматического, когнитивного и социально-психологического аспектов. Сложность исследуемого конструкта детерминирует необходимость проведения мультиметодного исследования с привлечением лингвокультурологического анализа, индуктивного метода, включающего наблюдение, анализ, сопоставление и классификацию языковых фактов, а также частнонаучных лингвистических методов: семантического анализа в дефинитивном варианте, контекстуального, текстового и стилистического типов анализа. Представляется, что интеграция различных методов позволит приблизиться к созданию полной дискурсной модели медиаслухов.

Помимо введения статья включает четыре раздела и заключение. Первый раздел посвящен описанию общей характеристики жанра и параметризации, положенной в основание жанровой модели рассматриваемых текстов. Последующие два раздела представляют собой обсуждение эмпирического материала в двух классических измерениях: содержания и формы. Содержательный аспект репрезентаций исследуемого текстотипа, раскрывающийся во втором разделе, рассматривается в тематическом ракурсе. Анализ формального устройства текстов в третьем разделе производится сквозь призму их 
функциональности с привлечением стилистического анализа. В четвертом разделе обсуждаются результаты исследования. В заключительной части наблюдения обобщаются.

\section{2. Параметризация жанрово-дискурсивных признаков текстов-слухов}

Научный контекст проблемы предполагает обсуждение ряда вопросов, имеющих первостепенное значение. Одним из них является вопрос о делимитации и идентификации слуха, связанный с его дефиниционными аспектами. Несмотря на длительную научную историю слухов, их понятийный статус в настоящее время весьма далек от окончательного разрешения. При анализе различных трактовок этого коммуникативного явления выявляется их достаточно серьезно выраженная противоречивость. Трактовки слухов зависят от парадигмальных оснований того или иного подхода, в рамках которого работают исследователи. Это позволяет высветить различные грани и аспекты исследуемого сложного конструкта. В силу ограниченности рамками статьи и невозможности озвучить все подходы ${ }^{1}$ к научной квалификации слухов обозначим основной вектор предлагаемой трактовки ${ }^{2}$. Принципиальная позиция выражается в том, что из многочисленного набора признаков феномена слухов базовой, инвариантной характеристикой их сущности является дихотомия - невалидность, неверифицируемость, неэвидентность передаваемой информации, но восприятие её как достоверной, на чем будут построены последующие рассуждения.

При изучении текстово-жанровых особенностей исследуемого явления мы отталкиваемся от двух оснований. Во-первых, это идея о том, что текстыслухи массмедиа выступают полноправными репрезентантами речевого жанра слухов, обладая всеми признаками текстуальности. Во-вторых, тексты сетевых изданий наряду со специфичными свойствами, накладываемыми на них особым медиальным форматом, рассматриваются нами как распространяемые через глобальную компьютерную сеть информационные продукты, которые сохраняют все основные жанрово-стилевые характеристики массмедийных текстов ${ }^{3}$.

Специфичность исследуемого коммуникативного поля массовой коммуникации заключается в том, что его массмедийная репрезентация уходит корнями в традиционную устную речевую практику, поскольку слухи по своей природе являются информационным жанром устной неформальной

${ }^{1}$ Особый интерес вызывает концепция Е.В. Осетровой, рассматривающей феномен слухов на русскоязычном материале как неавторизованную информацию в рамках речеведческого подхода на основе методологического треугольника: язык-текст-речь (Осетрова 2015).

${ }^{2}$ Подробный анализ признаков слухов в аспекте концептуального подхода см. в (Хакимова 2016 а, б).

3 Это коррелирует с позицией Т.Г. Добросклонской, согласно которой они [интернеттексты] «сочетают в себе признаки «сетевого» текста $<. .>$ с формально-содержательными особенностями печатных медиа-текстов» (Добросклонская 2013: 79). 
межличностной коммуникации. Нельзя не согласиться с мнением В.И. Карасика, согласно которому «институциональный дискурс в значительной степени может быть прояснен, если исследователь примет в качестве исходной посылки тезис о переосмыслении бытового дискурса в институциональный, поскольку бытовое, обыденное общение является генетически исходным и содержит в свернутой форме особенности общения на статусно-представительском уровне» (Карасик 2004: 236). Иными словами, первичный жанр всегда является элементом структуры вторичного, поскольку последний (жанртекстотип) создается на основе первичных речевых жанров. Фактически массмедийный жанр светских слухов можно рассматривать как вторичный по отношению к первичным речевым жанрам слухов и сплетен, относящимся к обиходно-бытовому общению. Опираясь на этот основополагающий принцип, необходимо учитывать два уровня типологизации речи: общей типологии речи, выделяемой в рамках классической лингвистики, лингвистики текста, и типологической классификации массмедийных жанров, основывающейся на учении о журнально-газетных жанрах в рамках медиалингвистики.

Несмотря на отсутствие единого принципа, на основе которого можно было бы описать все многообразие таксономии речевых жанров, лингвистыколлоквиалисты, работающие в русле общетипологического подхода, традиционно выделяют среди наиболее существенных признаков, влияющих на жанровую дифференциацию речи, следующие: характер коммуникации (официальная / неофициальная), вид коммуникации (личная / публичная), коммуникативная цель, число участников, вид адресата (личный / коллективный / массовый), образ адресата и его ролевой статус (равный / подчинённый, мужской /женский, подготовленный / неподготовленный (коллега / неспециалист), пассивность / активность адресата (Земская 1988: 43). В системе медиалингвистики при типологическом описании медиатекстов Т.Г. Добросклонская предлагается учитывать, помимо дихотомий, определяющих форматные и языковые свойства текстов, и их функциональные характеристики на основе разработанной ею концепции функционально-жанровых типов речи. Вследствие этого жанрообразующими параметрами текстов выделяются следующие: способ создания (авторский — корпоративный, устный — письменный); способ воспроизведения (устный - письменный); канал распространения (конкретное средство массовой информации: печать, радио, телевидение, Интернет); функционально-жанровый тип текста (новости, комментарий, features, peклама); тематическая доминанта или медиатопик (Добросклонская 2013: 44).

С точки зрения жанрово-стилевой принадлежности сплетни относят к информационно-фатическому жанру устного бытового общения («утоление «информационного голода» сочетается с приятным времяпрепровождением»), свойственного определенной группе лиц, обладающей некоторой системой коллективных знаний и представлений, имеющему нарративный характер, затрагивающему приватную сферу, включающему элементы косвенного осуждения третьего лица (Панченко 2007: 224, 232). В жанровой 
модели сплетни выделяются следующие базовые компоненты: (1) предмет речи, распадающийся на два компонента: а) исходный (предлагаемый адресантом) - информация об имевшем месте факте, событии, касающемся объекта сплетни, его неблаговидных поступков, б) воспринятый и часто дополненный некими элементами присочинений, содержащий эмоционально-оценочный компонент (трансформирующаяся часть); (2) участники коммуникативной ситуации - два лица: лицо, инициирующее распространение сплетни, и лицо, воспринимающее и усваивающее сплетню (может быть дальнейшим её распространителем) (Рабенко 2013: 47-48). В целом жанроведы признают неоднозначность исследуемого явления. Указывая на совмещение фатического и информационного начал речевого жанра сплетни, В.В. Дементьев справедливо замечает, что уже семантика данного существительного «характеризуется внутренней глубокой неоднородностью, охватывая сложный комплекс разных коммуникативных интенций, ситуаций, тем» (Дементьев 2010: 228).

Что касается жанра слухов и сплетен, принадлежащего к массмедийному дискурсу, его представителями являются тексты, появившиеся в результате взаимопроникновения речевых форм устного высказывания и письменного сообщения. По сути, медиаслух — это текст, передающий слух в письменной форме. Основные характеристики СМИ (обращенность к массовому, рассредоточенному адресату, общедоступность и оперативность) накладываются на свойства устно-слуховых сообщений (цепочечный характер передачи и, в конечном счете, охват диффузной аудитории в совокупности с быстротой распространения) и многократно усиливают их. Другими словами, медиаслухи выступают как гетерогенный тип текстов, образовавшийся на пересечении двух коммуникативных сфер: повседневно-бытового общения и массмедийного дискурса. Являясь изначально элементом неформальной коммуникации, слухи стали равноправным элементом институционального дискурса - дискурса СМИ. Наложение конститутивных свойств слухов и сплетен как элементов устной коммуникации на дискурсивные признаки массмедийных текстов привело к возникновению пограничного, специфического, сложного образования (гибридного по своей природе), существующего в континууме массмедиа и наделенного конкретными коммуникативно-дискурсивными характеристиками. Этот феномен является одним из ярких подтверждений существования устойчивых тенденций в развитии современной массовой коммуникации, отмечаемых многими языковедами: (1) сближение устно-разговорной и книжно-письменной сфер речи в целом и трансформация массмедийных жанров под влиянием экспансии в них фатического речевого поведения в частности ${ }^{4}$; (2) гибридизация жанровых форм, дискурсивных практик и конвергенция стилей, что способствует повышению персуазивного потенциала гибридного дискурса 5 .

\footnotetext{
${ }^{4}$ См., например, в (Лаптева 2015).

${ }^{5}$ См., на примере актовой речи в (Иванова 2017).
} 
Как утверждают Б.В. Дубин и А.В. Толстых, «печатные источники информации как бы пристроены сегодня к системе слухов, живут на них» (Дубин, Толстых 1993: 80). К этому можно добавить, что современные СМИ отличает гипертрофированное внимание прежде всего к новостям из мира успешных, богатых и знаменитых. «Слухи - это своеобразный “перпетууммобиле" для нынешней прессы, поскольку в случае дефицита достоверной информации есть возможность заполнить полосы именно ими» (Тертычный 2003: 73). Намеренно оставляя за рамками данной статьи диахронический аспект, заслуживающий отдельного, детального рассмотрения, лишь отметим, что эволюционный процесс развития текстотипа светских слухов в массмедийной англоязычной коммуникации, зиждущийся на культуре селебрити, предстает как ряд трансформаций структурно-композиционной формы, смещения семантических аспектов, стилистических модификаций, изменения вектора идеологической модальности ${ }^{6}$. Анализируя синхронический срез текстового континуума светских медиаслухов, с уверенностью можно констатировать, что не только «желтые» газеты и журналы, ориентированные на самую широкую аудиторию, «заточены» на эксплуатацию слухов из мира знаменитостей. Не обходит их стороной и таблоидная пресса, занимающая промежуточное положение по степени серьезности и аналитичности представляемых информационных материалов между откровенно «желтой» и качественной прессой ${ }^{7}$. Подобные издания всегда имеют в своем арсенале отделы, колонки, отдельные полосы светской хроники, помещающие сведения, основанные на слухах и сплетнях, чаще всего под рубрикой gossip column, celebrity gossip, celebrity, rumours, gossip, hot stuff, celebrities gone bad, showbiz, the dirt, hottest celebrity stories revealed, celeb news and dirt и мн. др. (ср.: светская хроника, отдел светской хроники, колонка слухов, светские сплетни). Данный жанр завоевывает все большую популярность, становясь самодостаточным и организуя отдельные издания с развитой системой тематических блоков. В качестве родового обозначения исследуемого медиаявления мы выбрали термин светские слухи (celebrity gossip) для обозначения указанного ряда смежных понятий, поскольку все они содержат материалы, репрезентирующие устойчивый текстотип массмедийной коммуникации, связанный с неподтвержденными новостями из жизни селебрити.

Архитектоника того или иного текстотипа может быть раскрыта посредством привлечения разных моделей и схем речевого жанра. С позиций жанроведения классическими текстообразующими признаками, предложенными еще М.М. Бахтиным, являются тематический, композиционный и стилистический аспекты (Бахтин 1979). В данной работе при составлении «портрета» жанра текстов-слухов о селебрити в медийном дискурсе акцент сделан

${ }^{6}$ См. работы англоязычных авторов разных периодов, например (Levin and Kimmel 1977; Walls 2001; Mole 2004; Chambers 2009).

${ }^{7}$ См. подробно топологию современных СМИ в (Мальцева, Лесная 2008) и характеристики таблоидных изданий Великобритании в (Лесная 2009). 
главным образом на двух проекциях: содержательной и структурной в силу ограниченной возможности в рамках одной статьи охватить все три основополагающих «кита» формирования жанра. Стилистический ракурс, несомненно, играет одну из ключевых ролей в построении текстового пространства и заслуживает пристального внимания и детального описания. Он будет привлекаться спорадически как вспомогательное средство, эвристический потенциал которого будет способствовать более глубокому пониманию формального устройства отдельных репрезентантов изучаемого жанра.

\section{3. Содержательный аспект жанра светских слухов}

Каждый жанр обладает своей иерархией признаков, определяющих его специфику. В случае массмедийного жанра светских слухов тематический фактор является наиболее существенным, поскольку определяет коммуникативные цели, способы их языкового воплощения и стилистические особенности текстов. Эмпирическим объектом журналистского дискурса в жанре «светские слухи» и выступают публичные персоны разной величины и ранга по шкале известности: актеры, представители шоу-бизнеса и другие деятели массовой культуры, спортсмены, политики, бизнесмены, представители высшего общества, что запечатлено в номинации рубрики. Национально-культурной спецификой исследуемого поля в англоязычном массмедийном дискурсе является ориентированность прежде всего на американские и западно-европейские известные лица, что обусловлено в частности отсутствием интереса у массовой англоязычной аудитории к инокультурным явлениям и в целом признанием доминирующей роли британской и американской культур в современном мире, сформулированной в концепции культурного империализма, компонентом которой является медийный или информационный империализм (Boyd-Barret 1977).

Исследуемое жанровое образование характеризуется наличием трех устойчивых тематических блоков, создающих его смысловой каркас. Обозначим их как топосы, которые связаны с различными аспектами жизни селебрити и которые распадаются, в свою очередь, на несколько доминантных топиков. Первый топос посвящен публичной стороне жизни «звезд», связанной с их профессиональной деятельностью и карьерой, их социальными взаимодействиями. Приведем в качестве примеров информативные заголовки некоторых статей:

(1) Cameron Diaz Confirms She Has "Actually Retired"

[https://www.dailymail.co.uk, 20.03.2018]

(2) Erica Mena Reportedly Joining “Love \& Hip Hop Atlanta” As Joseline’s

Replacement [http://gossiponthis.com, 12.12.2017]

\footnotetext{
8 Здесь и далее сохраняется оригинальный тип технического оформления заголовков текстов, приведенных из медиаисточников.
} 
(3) De Niro and Schwarzenegger's angry public stoush

[https://www.news.com.au, 10.12.2016]

(4) Dwayne 'The Rock' Johnson To Run For President In 2020?

[https://www.vanityfair.com, 12.05.2018]

Следующие два топоса охватывают частную жизнь знаменитостей и их окружения, где, по нашим наблюдениям, можно выделить два уровня «вторжения» СМИ в их «личное пространство». Применительно к ним можно использовать термины, предложенные Е. Сазоновым, - «мягкая» и «жесткая» степени вмешательства (Сазонов 2005), прямо или косвенно влияющего на репутацию знаменитых персон. Первый уровень интенсивности внедрения предполагает освещение событий приватной сферы, но тесно связанных с публичной благодаря пересечению личностной и социальной семантических сфер. Такие события «личной публичной» жизни быстро становятся достоянием широкого круга людей. Здесь наиболее разработанными топиками являются как положительно заряженные, так и трагические, отрицательно окрашенные события и ситуации: помолвка, брак, фертильность (беременность, рождение детей), развод, смерть, девиантное поведение в социуме и др., наглядной иллюстрацией чего служат следующие примеры заголовков статей:

(5) Kate Middleton: Pregnant with Twins?!

[https://www.thehollywoodgossip.com, 26.12.2017]

(6) Halle Berry \& Olivier Martinez will likely dismiss their divorce \& stay married [https://www.celebitchy.com, 30.09.2016]

(7) Meghan Markle Could Be (Unintentionally) Spilling Some Money

Secrets About the Royal Family [https:/www.bravotv.com, 30.05.2018]

(8) Drake Is a Good Dad! Allegedly. [https://www.thecut.com, 10.05.2018]

(9) WHO BIT BEYONCE'? HERE'S A LIST OF SUSPECTS

[http://www.celebuzz.com, 30/03.2018]

(10) What Really Happened The Night George Michael Died?

[http://www.celebritygossip.com, 03.01.2017]

Второй уровень вмешательства означает обращение прессы к табуированной проблематике, не подлежащей публичной огласке, агрессивное проникновение вглубь личностных взаимодействий, прежде всего семейных и неофициальных отношений, а также сугубо интимных аспектов приватной сферы человеческой жизни. В этом случае под прицелом журналистов оказываются любовные романы, адюльтер, ссоры, примирения, девиантное поведение в быту, отдых и пр. Особое место занимает обсуждение прессой информации, связанной со здоровьем, трансформациями внешности, сексуальными предпочтениями и другими проявлениями исключительно интимного характера. Типичными образцами топиков этого блока являются заголовочные комплексы следующих текстовых репрезентаций: 
(11) Did Ray J Cheat on His Pregnant Wife? Princess Love Hints at Marriage Troubles With Cryptic Social Media Posts

[http://gossiponthis.com, 03.02.2018]

(12) XXXTentacion's mom hints that he has a kid on the way

[http://www.celebuzz.com, 30.03.28]

(13) 'He really likes her' Lewis Hamilton and Winnie Harlow fuel dating

rumours at GQ Awards [http://www.express.co.uk, 10.09.2016]

(14) Is Brad Okay? Pitt Spotted Entering Infectious Disease Specialist's

Office [http://radaronline.com, 03.11.2016]

(15) Two women, one man to sue Usher over herpes claims

[http://gossiponthis.com, 30.01.2018]

(16) WHO'S THAT BOY? Madonna's daughter Lourdes looks loved-up as

she larks about with her rumoured boyfriend in New York

[https://www.thesun.co.uk, 10.11.2016]

(17) Jim Carrey alleged STD test has been submitted as evidence

[http://www.news.com.au, 30.10.2016]

Как известно, одним из факторов текстообразования является масштаб освещаемой проблемы, и, если информация имеет низкую содержательную ценность, как в случае текстов-слухов о селебрити, журналист по своему усмотрению придает ей статус актуального социально-релевантного события, смело нарушая этические границы. Данный журналистский прием М.Н. Ким обозначает как «объективацию субъективного», под которым кроется журналистский прием перевода личностно окрашенного события в разряд объективного факта (Ким 2005: 108).

Содержание обсуждаемого события, как правило, носит сенсационный характер. Сенсационность - доминантная типологическая характеристика жанра светских слухов англоязычных СМИ. Она проистекает из общей культуроспецифичной черты, присущей англоязычному массмедийному дискурсу и проявляющейся в повышенном интересе британских и американских СМИ к частной жизни высокопоставленных лиц, представителей королевских династий, деятелей политики, культуры и спорта (Добросклонская 2013: 189-190). В отношении исследуемых материалов можно выделить два уровня сенсационности: собственно сенсацию и скандал, поскольку в основе семантики лексемы сенсация лежит неожиданность, производящая волнующее впечатление (sensation - If a person, event, or situation is a sensation, it causes great excitement or interest [Collins 2018]), а скандал связан с нарушениями морально-этических норм, принятых в социуме, и поэтому всегда предполагает отрицательно коннотируемое сенсационное явление (scandal — talk about the shocking and immoral aspects of someone's behaviour or something that has happened; a situation or event that is thought to be shocking and immoral and that everyone knows about [Collins 2018]). Таким образом, типологически по степени оценки сенсационности разделим тексты на два типа: слухи-сенсации и слухи-скандалы. К первому типу отнесем эксклюзивные сообщения, горячие новости, экшн, ко второму — крупные скандалы, разоблачения. 
Рассматриваемые материалы зачастую отличаются имитацией сенсационности, псевдосенсационностью, когда в основе новости лежит искусственный слух, запускаемый СМИ в виде fake news. Ярким примером тому является слух-сенсация, «мишенью» которого оказывается известная голливудская актриса Кэмерон Диас. В статье под названием (18) Cameron Diaz Confirms She Has “Actually Retired" [http://www.celebuzz.com, 29.03.2018] содержится утверждение, что актриса объявила о завершении своей актёрской карьеры. Искусственная сенсация создается за счет того, что в качестве подтверждения приводится цитата из интервью самой актрисы:

(18) a. I'm totally down. I'm semi-retired, too, and I am actually retired.

Статью венчает комментарий колумниста, где употребляется лексема revelation (a fact disclosed or revealed, esp in a dramatic or surprising way [Collins 2018]) и привлекаются косвенные доказательства правдивости передаваемой новости в виде отсутствия свежих постов актрисы в мессенджере Инстаграм:

b. The saddest thing about this whole revelation is that we get zero new Cameron Diaz in our lives now. She's barely on social media either: her last Instagram was posted before the election.

Благодаря эффекту размножения, получившего название редупликации или мультипликации (reduplication, multiplication), данная новость тиражируется в многочисленных изданиях подобного типа, что напоминает массированную атаку по активному внедрению слуха и свидетельствует о возникновении целого нарратива, связанного с конкретным событием. Следующий ряд заголовков из различных медиаисточников свидетельствует об амплитуде колебания степени уверенности в достоверности обсуждаемой информации, начиная от сомнения, выражаемого риторическим вопросом в первом случае, до абсолютной убежденности, выраженной предикатным элементом pointblank (directly or straight; directly or rudely, without explaining or apologizing [Collins 2018]; ср.: категорически, наотрез, прямо, резко, решительно) в последнем примере:

(19) Cameron Diaz Says She's 'Actually Retired' But Has She? [https://www.ndtv.com, 02.04.2018]

(20) IT'S A HARD KNOCK LIFE Cameron Diaz confirms that she IS actually retired from acting [https://www.thesun, 30.03.2018]

(21) Cameron Diaz confirms she has 'actually retired' from acting [https://www.nickiswift.com, 30.03.2018]

(22) Cameron Diaz Confirms She's "Actually Retired" After All

[http://celebrityinsider.org, 30.03.2018]

(23) Yes, Cameron Diaz Has Retired From Acting: "I'm Literally..."

[http://wmagazine.com, 30.03.2018]

(24) Cameron Diaz point-blank confirmed that she's "actually retired," and let's process this together [https://hellogiggles.com, 30.03.2018] 
Наконец, этот ряд материалов итожит публикация (25) Cameron Diaz quits acting [http://www.dailymail.co.uk, 30.03.2018] в издании Daily Mail, в caмом названии которой слух перестает быть таковым и переводится в разряд фактов. Однако в самом конце выясняется, что раздутый искусственный слух оказывается следствием дезинформации, связанной с шуточным предположением коллеги К. Диас, Сэльмы Блэр (Selma Blair):

(25) a. I would have liked to do a sequel, but Cameron's retired from acting. She's like, 'I'm done'.

В результате псевдоновость окончательно развенчивается цитатой, приведённой автором статьи из твитта последней:

b. Blair later clarified her comments on Twitter. "Guys please, I was making a joke in an interview," Blair told her social media followers. "CAMERON DIAZ is NOT retiring from ANYTHING. And for more breaking news: I am NOW retiring from being Cameron Diaz's spokesperson".

Тем не менее, не каждое издание акцентирует внимание на такой развязке. Таким образом, подтверждается механизм превращения вымысла в факт, выявленный исследователями-социологами в области менеджмента организации, который заключается в том, что передается содержание сообщения, но не чувство уверенности / неуверенности относительно этого сообщения (Duboi, Rucker, Tormala 2011). Это означает, что при передаче этого coобщения от второго к третьему лицу его основное содержание сохраняется, а сомнение в достоверности утрачивается, что, очевидно, релевантно и для цепочечной передачи информации, выстроенной различными медийными изданиями, явно вторящими друг другу посредством перекрестных ссылок.

Подводя итоги, подчеркнем, что в качестве информационного повода выступают любые события из жизни богатых и знаменитых представителей англоязычного мира, включая самые тривиальные, которым искусственно придается статус сенсации или скандала. В следующем разделе будут рассмотрены речевые формы, в которые облекаются текстовые конкретизации изучаемого жанра.

\section{4. Формальная организация текстов-слухов о селебрити}

Известно, что важнейшим жанроформирующим принципом, обусловливающим выбор формы, в рамках текстоцентрического подхода является интенциональный аспект. При этом, несмотря на формирование отдельных текстотипов с общей интенцией, не вызывает сомнения полиинтенциональность медиажанров (Дускаева 2012), обладающих «симультанным пучком интенций разного уровня» (Коньков 2014: 181), что детерминирует открытость системы жанров массовой коммуникации, лабильность их границ как в отношении структуры, так и языковой репрезентации. Генеральной интенцией медиасферы декларируется информирование, поскольку оно присутствует в любом медиажанре, к которому добавляются другие интенции (Шмелева 2014: 
53). В этой связи полиинтенциональность жанра celebrity gossip можно выразить формулой: «информирование + развлечение». Здесь следует заметить, что в генристике, развивающейся на основе теории речевых актов, бытует точка зрения, согласно которой все речевые жанры существуют исключительно между двумя полюсами фатического или информативного коммуникативного намерения (Н.Д. Арутюнова, Т.Г. Винокур, В.В. Дементьев). В русле этой идеи Н.А. Корнилова толкует речевой жанр как «исторически сложившийся текстотип, обслуживающий определённую сферу человеческой деятельности: < ..> определяется коммуникативной целеустановкой (совокупностью частных целеустановок, воплощённых в речи) говорящего, стилистико-композиционным оформлением и тяготеет к одному из полюсов человеческого общения - фатическому или информативному» (Корнилова 2014: $57-58)$.

Таким образом, можно констатировать, что иллокутивный потенциал исследуемого нами жанрового текстотипа celebrity gossip охватывает диапазон доминантных коммуникативных задач, размещающийся между реализацией фатической и информативной функций, вырастающих из интеграции первичного речевого жанра личностно-ориентированного, разговорно-бытового дискурса и вторичного журналистского жанра институционального массмедийного дискурса, что отнюдь не исключает комплекса частных интенций, реализуемых отдельными текстовыми конкретизациями. И этот факт подтверждается структурно-композиционном аспектом медиаслуха, проявляющимся в дипластичности его формы, репрезентируемой наложением структур журнальной статьи и устного сообщения - слуха per se. Полиинтенциональность рассматриваемого жанра обусловливает размытость его границ и диффузность форм, задействованных в различных дискурсивных практиках. Это проявляется в том, что стандартный набор тем в рамках светских слухов оформляется в виде широкого диапазона типизированных функциональнотекстовых структур. Поскольку «интенция развлечения не выработала «своих» жанров, а реализуется в информационных (инфотейнмент)» (Майдурова 2011: 39), а слух - это прежде всего новость о событии (актуальная, оперативная, востребованная информация), тексты жанра celebrity gossip создаются, как правило, на основе первичных журналистских информационных форм, таких как новостная заметка, событийная заметка, новостная статья, информационная заметка, информационное сообщение, информационная корреспонденция, выделенных в рамках учения о журнально-газетных жанрах отечественной медиалингвистики.

Диапазон информационных вариантов представления слухов из мира селебрити весьма широк: от небольших по объему новостных заметок до достаточно объемных информационных сообщений, представленных в свою очередь различными стереотипными речевыми действиями: монолог, диалог, описание, рассказ и пр. Каноническая модель текста медиаслуха зависит от использованной типовой жанровой формы его презентации. Несмотря на 
многообразие форм, в которые «упаковываются» слухи, четко просматривается структурно-композиционный инвариант текстов рассматриваемого жанра, где базовой интенцией является информирование. Устойчивость структуры медиа-слуха о селебрити обеспечивает построение по принципу «жесткой новости» или «перевернутой пирамиды» (Дейк 1989: 17), когда наиболее важная информация предоставляется в сильной позиции - начале статьи (заголовке и лиде) и далее разворачивается в виде деталей и подробностей. Приведем пример событийной заметки - одной из широко эксплуатируемых типовых форм в рамках исследуемого жанра.

(1) Brooke Mueller hospitalised for psychiatric evaluation, according to reports

CHARLIE Sheen's ex-wife has been hospitalised for a psychiatric evaluation. According to TMZ, a woman claiming to be Brooke Mueller's mum called the Utah Highway Patrol and told them Muller might not be mentally stable.

The troopers tracked her down as she was driving in her SUV with the sevenyear-old twins she had with Sheen.

The children's nanny was also in the car at the time.

Mueller was taken to hospital and the twins are now being looked after by a family member.

Mueller and Sheen were married from 2008 to 2011 [https://www.news.com.au, 18.11.2016].

Данная заметка демонстрирует модель коммуникативной ситуации, типичной для текста-слуха о селебрити, - это необходимость сообщения о существовании актуальных, но неверифицированных сведений о произошедшем событии или сложившейся ситуации, связанной со знаменитостью. В основе приведенного текста лежит неподтвержденная информация о психической нестабильности Брук Мюллер, бывшей супруги американского актера Чарли Шина, «вмонтированная» в событие, связанное с её принудительной госпитализацией с целью психиатрической экспертизы. Факт означенного состояния медиаперсонажа оказывается при внимательном рассмотрении неверифицированным, поскольку проявляется через анонимный источник информации, что вербализуется лексемой claiming и неопределенным артиклем (a woman claiming to be Brooke Mueller's mum), а также сочетанием according to reports, эксплицирующим ссылки на другие СМИ в качестве подкрепления достоверности сведений. Приведенная заметка реализовывает несколько типовых речевых действий, порожденных типовой ситуацией, - сообщение о событии, краткое описание обстоятельств произошедшего, констатация его последствий, дополняющая справка (в данном тексте - уточнение истории брачных взаимоотношений семантических субъектов в одной пропозиции).

Наблюдения показывают, что наиболее востребованной журналистской формой в исследуемом жанре является новостная статья (story в англоязычной традиции) - более объемное произведение в сравнении с заметкой и более сложное в плане речевой разработки содержания. С целью выявления 
образца текстопостроения и восприятия рассматриваемого текстового жанра в лингвокогнитивной плоскости он может быть представлен в виде прототипической схемы, т.е. наиболее характерной структуры (суперструктуры в терминах Т. ван Дейка). Детальная схема текста-прототипа исследуемого жанра в рамках типовой структуры новостной статьи включает следующие инвариантные сегменты: заголовочный комплекс, лид, введение в проблему, постановка проблемы в виде представления различных мнений (минимум двух) об обстоятельствах (причинах, характере протекания, следствиях) события и столкновения этих точек зрения, обобщенная оценка.

«Три кита» (информативность, доступность и развлечение), на которых держится инфотейнмент, понимаемый как способ подачи информации современными СМИ в развлекательной форме, реализуются уже на уровне заголовочного комплекса. Особенностью заголовка является большой объем и, как результат, высокая степень его информативности, т.е. суть происходящего транслируется в сжатом, но исчерпывающем виде - пропозиции о событии. Другим заметным свойством заголовка выступает его броскость: используются различные оформительские уловки (часто - крупный объем, жирный шрифт и пр.), не только «сигнализирующие» о значимости и эксклюзивности передаваемой информации, но и делающие её более привлекательной и с этой точки зрения более доступной для адресата.

Лид, также считающийся сильной позицией медийного текста, представляет собой концентрацию всех важнейших компонентов передаваемого сообщения. Что касается развертывания самого сообщения, анализ показывает его многослойный характер. Поскольку к базовым характеристикам информационного дискурса в рамках журналистики традиционно относят новостную окраску (новость в отечественной журналистике, как правило, не выделяют в качестве отдельного жанра), актуальность, оперативность, объективность, документальность (формируемая достоверностью, точностью и конкретностью), правдивость, лаконичность, сенсационность (Ким 2005: 208-212), демонстрируя стремление к объективности изложения материала и подчеркивая достоверность передаваемого слуха, авторы статей прибегают к использованию различных эвиденциальных компонентов, «склеивающих» смысловые сегменты текста. Одним из ключевых элементов, включенных в заданную устойчивую модель, являются многочисленные ссылки на источники информации. Другим текстообразующим фактором является введение в текст элементов интервью, представленных в широком диапазоне цитат в виде прямой речи, косвенной речи, отдельных словосочетаний, выделенных кавычками, авторами которых являются сами «мишени» слухов, лица из их близкого окружения, эксперты (в социальной парадигме - «лидеры мнений»). Отдельного внимания заслуживает тот факт, что зачастую в качестве надежных источников преподносятся другие медийные издания, что вызывает эффект сарафанного радио: информация, передаваемая одним источником, начинает тиражироваться другими СМИ, выступающими, в свою очередь, 
последующими её ретрансляторами. В результате текст наполнен «голосами», что создает эффект пересказывательности, цепочечности передачи сведений, характерной для устно-«слухового» канала массовой коммуникации. Многочисленные перекрестные ссылки, посредством которых одни издания вторят другим, свидетельствуют о том, что СМИ выступают не посредниками, передающими некую информацию, а конструируют собственную реальность посредством самореференции - отсылки к событиям, созданным или воссозданным все теми же СМИ, замеченную еще Н. Луманом (Луман 2005). Эти компоненты, по замыслу авторов, не только усиливают верификативный потенциал представленной информации, но и интегрируются в текст в качестве полноправной составной части, играя самостоятельную роль в конструировании текста и развивая его фактологическую основу. В большинстве случаев авторский текст практически не заметен и «тонет» в череде обильных цитат и ссылок. Приведем в качестве примера скандальный слух об адюльтере жены известного американского тележурналиста Ларри Кинга, оформленный в виде небольшой статьи:

(2) Larry King brushes off talk of wife's alleged affair

Larry King is speaking out about wife Shawn King's alleged affair.

"I've been in the business now maybe 60 years and I've dealt with rumors long time. [I've] interviewed people involved with rumors, and rumors are what they are - rumors," Larry said in a joint interview with Shawn that aired Friday on Hallmark Channel's "Home \& Family." "And to tell you the truth, I don 't pay any attention to them."

The National Enquirer reported this week that Larry's wife of 19 years has been carrying on a yearlong affair, with Page Six revealing his identity as communications specialist Richard Greene. Despite a brief breakup, the tabloid claimed Shawn "was trying to desperately arrange a passionate hookup with her lover via Facebook sex messages" as the story went to press. Lawyers for the couple called the Enquirer's report "inaccurate." Shawn said in Friday's interview, "You just have to develop a shell around yourself and not get hard on the inside. And stick together."

Despite the united front Larry, 82, and Shawn, 56, showcased for the cameras, as an insider told Page Six, the couple not only sleep in separate bedrooms inside their Beverly Hills estate, but their marriage has effectively been over since about 2010. They wed in 1997 [https://pagesix.com, 24.08.2016].

В данной текстовой репрезентации бросается в глаза фактическое отсутствие авторского текста, за исключением последнего предложения-справки, напоминающего о дате регистрации брака обсуждаемых «мишеней». Весь текст выстроен на основе цитат и ссылок во всех означенных способах воплощения на журнал The National Enquirer и инсайдера (insider - a member of a specified group; a person with access to exclusive information [Collins 2018]; ср.: хорошо осведомлённый человек, конфиденщиальный источник). 
Другой особенностью такого рода текстов является повторяемость их отдельных компонентов от текста к тексту в рамках нарративного ряда, посвященного одному и тому же событию, но с течением времени обрастающего различными подробностями, дополнениями, что, как доказано социологами, характерно для хождения «бродячих» (устных) слухов, подверженных различным трансформациям. Эти признаки демонстрирует текст, являющийся частью разрастающегося нарратива, связанного с вышеприведенным сексуальным скандалом, под названием (3) Larry King 'embarrassed and furious' over wife's alleged affair [https://pagesix.com, 26.08.2016]. Здесь повторяются следующие элементы предыдущей публикации (2):

(3) a. Lawyers for Larry and Shawn have called the Enquirer story "inaccurate."

b. The insider revealed that Shawn and Larry's marriage has effectively been over since around 2010 and that the couple sleep in separate rooms in their Beverly Hills home.

Информационным поводом для очередной статьи (4) EXCLUSIVE Meet the man allegedly having an affair with Larry King's wife [https://pagesix.com, 26.08.2016] становится вновь открывшаяся деталь - идентификация личности любовника героини Шон Кинг. За исключением нескольких сегментов, она фактически вторит предыдущей публикации (3), поскольку все элементы последней воспроизводятся точно или почти без изменений:

(4) a. Attorneys representing Shawn and Larry, as well as a rep for Greene, called the story of the affair "inaccurate."

b. Meanwhile, insiders tell Page Six that Larry, 82, was blindsided by the revelation of the alleged tryst.

c. Sources say that Larry believed his wife of 19 years was faithful to him and only learned about her romance with Greene when the Enquirer contacted his reps for comment.

d. Shockingly, an insider told us that Shawn, 56, met Greene when he was a guest on a podcast she co-hosts with her husband, "Back and Forth With Shawn and Larry."

e. "He's heartbroken," a friend of Larry's told us. "He's embarrassed and furious."

f. The source added that although Shawn - who the Enquirer reported on Wednesday had sent nude pictures and had "steamy afternoon sex sessions" with her boy toy - is still living with Larry after the news hit, the veteran broadcaster hasn't made a decision on whether to file for divorce.

g. In fact, the insider said that before the scandal broke, Shawn "was ready to divorce Larry for this guy, but the guy was hesitant about it."

$\mathrm{h}$. The insider further revealed that Shawn and Larry's marriage has effectively been over since about 2010 and that the couple sleep in separate rooms in their Beverly Hills, Calif., home. 
Важный аспект, который необходимо также принять во внимание при описании канонического образца исследуемого жанра, связан с различиями в русской и английской национальных научных традициях, что детерминирует несовпадение классификаций медийных жанров и значительно осложняет разработку исследуемой проблематики. Нет единообразия и в стратификациях англоязычных медийных жанров в концепциях разных авторов. На наш взгляд, более последовательной представляется концепция функциональножанрового типа текста, предложенная Т.Г. Добросклонской на основе одного, четкого критерия - функционального: она, «с одной стороны, помогает обозначить его функциональную направленность в плане соотношения сообщения - воздействия, с другой — соотнести текст с одним из основных видов медиаречи, так или иначе притягивающих все остальные жанры и разновидности, как-то: новости, информационная аналитика и комментарий, features (тематические авторские материалы), реклама» (Добросклонская 2014: 20). Особо отметим культуроспецифичность прецедентного феномена features в англоязычной массмедийной практике, что обусловливает его неоднозначную трактовку. Из информационных, аналитических и художественно-публицистических групп текстов, традиционно выделяемых в рамках отечественной теории жанров, производимых СМИ, группа features, традиционно cooтносится с публицистикой, причисляемой к «авторской» журналистике. Но специалисты по англоязычной медиакоммуникации указывают на более широкий диапазон его концептуального поля, явно выходящий за пределы публицистики. Оно включает материалы (1) сенсационного характера, (2) тематически привязанные, т.е. соотнесенные с устойчивым медиатопиком, регулярно освещаемым в постоянных рубриках тех или иных СМИ (в том числе так называемые human interest stories, celebrity interviews and profiles и др.), (3) самые разнообразные по форме (от заметки до очерка и анекдота) и протяженности (600-2000 слов), (4) мультиинтенциональные по целеустановке: информирующие, оценивающие, воздействующие, развлекающие 9 Дискурсивные практики в рамках жанра светских слухов, помимо использования классических форм, относящихся к информационной медиагруппе, «островов стабильности» (термин В.И. Конькова (2014)), также демонстрируют структурно-композиционные, функциональные и стилистические характеристики текстов, облеченных в форму features. К устойчивым слагаемым образца данной группы можно отнести их достаточно свободную структуру, подчиняющуюся принципу «мягкой новости» или «обычной пирамиды», при которой конец статьи не менее важен, чем начало. Кроме того, с позиций авторской установки в публицистических жанрах features доминирует интенция убеждать, рационально и эмоционально воздействуя.

Жанрово-стилевые характеристики светских слухов базируются на особенностях широкой разновидности форм, относимых к группе features. Одной

\footnotetext{
${ }^{9}$ См. подробный анализ данного понятия на основе различных словарей в (Добросклонская 2013: 64-68).
} 
из таких часто эксплуатируемых форм является очерк. В отечественной журналистике традиционно считается, что в нем соединяется репортажное (наглядно-образное) и исследовательское (аналитическое) начало. «Причем «развернутость» репортажного начала воспринимается как преобладание художественного метода, в то время как упор автора на анализ предмета изображения, выявление его взаимосвязей выступает как доминирование исследовательского, теоретического метода» (Тертычный 2000: 117). Обычные слухи могут «камуфлироваться» как в форму проблемного, так и портретного очерка. Главной типоформирующей характеристикой подобных публикаций (зачастую неавторских, коллегиальных текстов) является крайне низкая содержательная ценность обсуждаемых ситуаций и событий. Авторы уверены, что сюжеты представляемых ими материалов настолько драматичны и непредсказуемы, а раскрываемые тайны столь заманчивы и сенсационны, что сами по себе способны привлечь внимание читателя и восприниматься им на уровне информации, черпаемой из самых захватывающих художественных произведений. Тривиальность набора фактоидов, которые понимаются как недостоверные или ложные (непроверенные или заведомо ложные) утверждения, выдаваемые за достоверные, определяют степень «аналитичности» дискурсивных практик, маскируемых под оболочкой проблемного очерка, а по сути являющихся псевдоаналитикой. Обсуждаемая «проблемная ситуация» сводится к описанию пикантных подробностей банальных ситуаций из частной и интимной жизни «мишени» слуха, например, анализу причин развода или проблем в личных отношениях той или иной знаменитой пары. Ярким подтверждением этому служит ситуация разрыва любовной связи американской певицы, актрисы Тейлор Свифт и британского актера Тома Хиддлстона, ставшая информационным поводом для публикации (5) The real reason Taylor Swift and Tom Hiddleston split [http://www.nickiswift.com, 12.09.2016]. Прототипические структуры очерковых текстов, как правило, включают ряд субкомпонентов, что обусловливает значительный объем таких речевых произведений. В рамках репрезентантов жанра светских слухов они часто представлены в виде вопроса или ассертива в подзаголовке и развернутого ответа и спекуляций на данную тему, иллюстрацией чего являются заголовки сегментов вышеупомянутой публикации: Sources claim it was 'amicable'; Was he using her for fame?; They recently had a 'major argument'; They got together way, way too fast; Swift was fresh out of a relationship; And then her feud with Kanye West erupted again; They were dating long distance.

Исследовательский метод, требуемый при создании проблемного очерка, имитируется привлечением мнения «эксперта» (в терминах социальной психологии - «лидера мнения») при трактовке «проблемы» и путей её решения, при этом широко используется терминосистема релевантной научной области. Данное свойство ярко проявляется в статье (6) Body Language Expert Judi James Says Trump's Marriage Is Crumbling [http://www.hollyfame.com, 22.09.2017], посвященной якобы рушащимся отношениям действующего 
президента США Дональда Трампа и его супруги Мелании Трамп. Текст представляет собой достаточно подробное описание спекуляций, построенных на анализе «языка тела» Д. Трампа и М. Трамп, со ссылкой на мнение «эксперта» и привлечением общенаучной и частнонаучной терминологии из области психологии, используемой для придания псевдонаучной аргументации правдоподобного характера, убеждающего реципиента в истинности представленной информации, например, expert, dissect (to examine critically and minutely [Collins 2018]), deeply analyze, significant signs, tie-signs, signals, PDA (Public Display of Affection - аббревиатура-неологизм недавно зафиксированная в [Collins 2018]):

(6) a. According to the body language expert, Judi James, ever since Donald Trump became the US president, Melania's body language is saying: Help me...

b. Judi James of Mirror Online decided to deeply analyze First Lady's body language during several of her public appearances, and she went on to dissect Melania's behavior during her rally speech for her husband.

c. "That hand movement plus the small, spontaneous-looking smile and laugh that follows suggests Melania was both surprised and pleased by the cheers and about to get into her stride," says James.

d. And we all know that shuddering is a sign of fear, revulsion, and unhappiness altogether.

e. The Trumps are certainly lacking these spontaneous PDAs.

Эффект «объективности» публикации умножается задействованными в ней лексическими элементами и синтаксическими структурами, свойственными аргументативному дискурсу, типа Certainly, On the other hand, And we all know..., If we take a look (you watch)... we can (you see); That hand movement plus the small, spontaneous-looking smile suggests...). Кроме того, персуазивными средствами, способствующими убеждению адресата в достоверности передаваемой точки зрения, выступают художественные приемы, одним из которых становится риторический вопрос: So, is their marriage crumbling before our eyes? Другим мощным инструментом является стилистический синтаксический прием антитезы, применяемый для противопоставления переживающей якобы сложности во взаимоотношениях супружеской пары Трампов, описанной в первом субкомпоненте текста, другой чете - бывшим хозяевам Белого дома, Бараку и Мишель Обамам, имеющим, по мнению автора текста, более гармоничные отношения и сравниваемым с Трампами в другом сегменте: Barack and Michelle Obama, On The Other Hand...

Надо отметить, что Д. Трамп является одним из объектов, к которому приковано пристальное внимание светской колумнистики, более того, одной из персон мира селебрити, в наибольшей степени подвергающейся маргинализации и демонизации в светских слухах. Излюбленной темой создателей подобных текстов являются его отношения с другими членами семейства Трампов, в которых, по версии текстов-слухов, он проявляет себя как 
недостойный муж и отец. Неудивительно, что он зачастую выступает «мишенью» слухов, облеченных в форму другой разновидности очерка - портретного. Сосредоточенность на герое и фоне в нетривиальной ситуации, отличающая фактуальный план указанного жанра, стремление «раскрыть самое главное - показать, каким ценностям служит этот герой, в чем видит смысл своего существования» (Тертычный 2000: 124), в репрезентациях исследуемого типа сводится к портретированию тех сторон личности и фактов её биографии, которые имеют сугубо интимный, порой пикантный характер и относятся к категории того, что должно быть скрыто от постороннего взгляда («грязного белья» или «жареных фактов»), но способного, по мнению авторов, привлечь и удержать внимание массового адресата. В связи с этим зачастую важной типоформирующей характеристикой слухов, заключенных в форму feature, оказывается введение в текст элементов журналистского расследования (investigative feature), задача которого состоит в выявлении истинного положения вещей. Так, в очерке соединяются реальные факты биографии героя и разнообразная неэвидентная информация, искусно интегрируемая в фактуальную канву текста. При этом оказываются задействованными лингвистические ресурсы эпистемической модальности со значениями абсолютной уверенности в достоверности представляемой информации, обладающие серьёзным потенциалом персуазивности. И наконец, в отличие от светских слухов, оформленных в виде информационно-новостных материалов, в репрезентациях, облеченных в форму feature, в стилистическом плане типологическим свойством выступает иронический тон, свойственный фактически всем публикациям подобного рода. Он воплощается в текстах посредством насыщения экспрессивно-эмоционально-оценочными компонентами, помогающими, с одной стороны, доступно изложить информацию, и, с другой, усилить интенцию убеждения адресата в правильности представленной точки зрения посредством яркости образной составляющей.

Проиллюстрируем данные положения на примере портретного очерка (7) Things you didn't know about Donald Trump's wife [https://www.nickiswift.com, 10.11.2017], объектом журналистского интереса в котором является Мелания Трамп. Обещание в заманчивом заголовке статьи «вскрыть всю правду» эксплицируется маркерами эпистемической модальности: things you didn't know about. Биографические данные М. Трамп представлены сквозь призму биографии супруга, причем характеризация субъектов осуществляется на основе их противопоставления посредством приема антитезы, с помощью которой образ Д. Трампа явно подвергается маргинализации, что четко выражено в первой пропозиции лида:

(7) a. Although Donald Trump has made quite a show for himself, his current wife, Melania, has mostly kept to the background.

На уровне структуры всей публикации в глаза бросаются параллельные синтаксические конструкции, в которые встроены подзаголовки к каждому 
сегменту текста, конкретизирующие заголовок и представляющие факт за фактом, неизвестные, по мысли адресанта, широкому кругу читателей. Повтор местоимения she привносит особую ритмику в каждую пропозицию, придавая выразительность и усиливая суггестию достоверности предъявляемых сведений: She used to be a model, She met Donald while he was dating someone else, She stays out of Donald's campaign, She doesn't always agree with him, She's Trump's third wife, She's barely older than her step-kids. Вся публикация посвящена тривиальной тематике и построена на смешении реальных фактов и фактоидов о ситуациях и событиях из биографии супруги Д. Трампа, что подтверждается наличием в приведенных сегментах базовых элементов текстового инварианта светских слухов: эвиденциальных маркеров слухов (assumption, gossip), цитаций в виде прямой речи, включая целые высказывания и закавыченные отдельные сочетания, косвенной речи, эпистемических маркеров, выражающих большую степень уверенности автора в достоверности информации (Anyone knows), а также ссылок на другие издания для подкрепления доказательной базы - в этом отношении примечателен факт двойной ссылки в первом сегменте: told Parenting magazine (via the New York Post). Помимо этого, постоянно подчеркивается сенсационность и скандальность представляемой информации: filled with the kind of gossip and scandal, a scandalous affair with Marla Maples, kept the New York Post in business, put the entire Kardashian family to shame, now-infamous interview that the Trumps gave to radio shock-jock Howard Stern. Последние два содержат американские прецедентные имена Kardashian и Howard Stern, символизирующие крайне высокую степень скандальности происходящего. Стереотипность текста для исследуемого жанра подкрепляется высокой степенью экспрессивности в персуазивных целях, реализуемой посредством аффективов boasted, long and painful years, infamous interview (infamous - causing or deserving a bad reputation; shocking [Collins 2018]), разговорно-сниженной лексики типа shock jock (US, slang a radio talk-show host who features material that is deliberately offensive, vulgar, etc. [Webster's 2018]), коннотациями иронии, проявляющейся в семантике как отдельных сочетаний типа his first time at the rodeo (rodeo - In the United States, a rodeo is a public entertainment event in which cowboys show different skills, including riding wild horses and catching cattle with ropes [Collins 2018]), так и целых пропозиций, например, в пропозиции паремического типа:

b. Well, as they say in the White House, if the Lincoln Bedroom's rockin', don't come a-knockin'.

Границы жанра светских слухов столь подвижны, что дают возможность интегрироваться качественно отличным по структуре дискурсивным практикам, в частности, принимающим форму анекдота, что придает искомому жанру признаки ироничного дискурса. По оценке Н.А. Корниловой, анекдот, традиционно относимый к этикетным жанрам разговорно-бытового дискурса, 
проникает в медиакоммуникацию, развивая её праздноречевой аспект (Корнилова 2014: 58). В рамках жанра светских слухов он представлен в разновидности юмористического рассказа и может быть обозначен как адаптативный вариант (жанровое заимствование), т.е. обращение к чужим образцам без потери жанровой идентичности (в терминах М. Войтак [Войтак 2014: 10]), репрезентантом которого является нижеследующий текст.

(8) Marc Anthony finds out he's not as famous as he thinks he is

Marc Anthony struck out at Game 1 of the World Series.

The two-time Grammy winner - and Jennifer Lopez's ex-husband - was in the stands watching the Indians play the Cubs on Tuesday night in Cleveland when, we're told, he wanted a beer and popcorn mid-game.

His bodyguard didn't want to leave the action, and the star alone, to grab the snack, and, according to a spy, told an usher at Progressive Field: "This guy is a famous singer and I'll pay you to go get him a beer and popcorn."

But the usher rebuffed the offer, saying that he "[already has] a job."

A source said, "Marc's the real diva. J.Lo has nothing on him!"

The curious Cleveland usher then got in a dig at Anthony, asking, "Are you really a famous singer?" [https://pagesix.com, 26.10.2016]

Персонажем «текста-слуха» является американский певец Марк Энтони. Для выражения своего отношения к герою публикации адресант прибегает к иронии прежде всего в сильных позициях текста. Заголовок статьи, умножаемый лидом и заключающим высказыванием, выполняет речевую функцию издевки. Особенно примечателен лид, представляющий собой каламбур, peaлизованный через игру слов, связанную с использованием фразового глагола, входящего в арсенал бейсбольных выражений: be struck out (In baseball, if a pitcher strikes out a batter or if a batter strikes out, the batter fails to hit three balls thrown properly by the pitcher, and is out [Collins 2018]; ср.: провалиться, потерпеть неудачу, опозориться, выйти из игры). Шутливо-комический эффект придается тексту за счет обыгрывания ситуации бейсбольного турнира, в которой находится герой, и обозначения «провала» звезды шоу бизнеса вследствие её неузнаваемости среди обывателей, в частности, обслуживающего персонала и последующего за этим пренебрежительного обращения. Среди приемов комического письма автор использует сатирические приемы, благодаря которым ирония приближается к степени сарказма, в частности, употребляет сочетание the real diva в отношении певца-мужчины (diva- $\mathrm{Br}$, a highly distinguished female singer; prima donna [Collins 2018]; 2) Am, a leading woman singer, esp. in grand opera [Webster's 2018]) и последующего его сравнения с бывшей женой - мега-поп-дивой Дженнифер Лопес. Этот факт обыгрывается в публикации посредством прямой речи: “Marc's the real diva. J. Lo has nothing on him!".

Таким образом, формальное устройство жанра медийных слухов имеет многоуровневую организацию, включающую разнообразные формы журналистского дискурса. 


\section{5. Обсуждение результатов}

Многогранность и множественность проявлений изучаемого феномена обусловила интерес к изучению слухов в рамках лингвистических исследований. Выбор светских слухов, циркулирующих в массмедийном пространстве англоязычного дискурса, в качестве объекта настоящего исследования обусловлен тем фактом, что они являются типичными элементами «слуховой» коммуникации и позиционируются как собственно слухи.

Представляется, что типологически тексты-слухи, существующие в рамках массмедийного дискурса, являются полидискурсивным продуктом, демонстрирующим:

- наложение устного и письменного коммуникативных каналов,

- проникновение неформальной сферы коммуникации в формальную, институциональную сферу,

- стилевую разомкнутость, выражающуюся в конвергенции обиходнобытового и массмедийного дискурсов,

- мультимедиальность в смысле технико-форматных возможностей,

- полифункциональность, реализуемую посредством нескольких коммуникативных целеустановок.

Коммуникативные функции слухов как устного информационного жанра и медиатекста наслаиваются друг на друга: информативная, диалогическая (фатическая) функции слухов и медиатекстов и гедонистическая, рекреативная функции сплетен и популярных СМИ, что приводит к созданию гибридного информационного продукта, характеризующегося высокой степенью конвергенции.

Одним их значимых компонентов массмедийных слухов выступают светские слухи (celebrity gossip). Светская колонка - типично англо-американское явление, связанное с культурой селебрити, получившее наибольшее распространение в англоязычной журналистике и имеющее давние традиции. В орбиту исследования данного феномена нами был вовлечен жанрово-текстовый анализ медиатекстов, конструирующих слухи о селебрити. Описание жанровой специфики дискурсивных практик, составляющих коммуникативное пространство изучаемого жанра, осуществлялось на основании классического методологического треугольника: содержание, форма и функция.

Исследуемый жанр представляет собой сложное коммуникативное событие, функционирующее в рамках массмедийной коммуникации и направленное на реализацию ряда функций. Содержательная типологизация текстовслухов о селебрити лежит, прежде всего, в тематической плоскости их матрицы. Анализ выявил широкий диапазон топосов, эксплуатируемых создателями исследуемых текстов. Предметом журналистского интереса оказываются топики, связанные как с публичной сферой деятельности селебрити, так и их приватной сферой. При этом ядерной, прототипической составляющей жанра являются спекуляции на устойчивые топики, связанные главным образом не с социальной, а с приватной, часто интимной сферой жизни 
знаменитых медиа-персонажей, что, очевидно, обусловлено тем, что сплетни как первичный речевой жанр, по оценке специалистов, демонстрируют узость проблематики, связанной с обсуждением лиц с элементами оценки их поведения, выражающейся в диффамации обсуждаемых «мишеней» при непременном условии их отсутствия. По нашим наблюдениям, в отношении частной жизни селебрити фактически нет запретных тем. Доминантными характеристиками передаваемых сведений являются сенсационность и скандальность. Несмотря на тривиальность описываемых типичных ситуаций и событий, материал зачастую подается как эксклюзивный, а погоня за сенсацией приводит к псевдосенсационности информации, приобретающей характер фейковых новостей. Это напрямую связано с функциональной компонентой жанровой системы светских медиаслухов.

Функциональность исследуемого текстотипа помещается между полюсами различных интенций. Иллокутивный потенциал рассмотренной текстовой модели состоит из совокупности четырех интенций: информативной, рекреативной, оценивающей и воздействующей. Вкупе с интенцией информирования, являющейся генеральной интенцией для всех журналистских жанров массмедийного дискурса, интенциональной доминантой предстает гедонистическая установка, относящая исследуемый жанр к развлекательному ресурсу медиасферы. Причем способ упорядочения целеустановок можно охарактеризовать следующим образом: «информируя, развлекать и побуждать», т.е. склонять к определенному мнению и оценке ситуаций, событий, происшествий, связанных со знаменитыми «мишенями» слухов, что, очевидно, обусловливает наличие дополнительной - прескриптивной функции слухов, связанной с социализацией индивидов и социальным контролем и требующей дополнительных усилий со стороны исследователей дискурса массмедиа.

Коммуникативная установка автора текста обусловливает использование той или иной типовой жанровой формы презентации информации. Исследуемые тексты относятся к категории нежестко стандартизированных в структурно-композиционном плане образований. Не имея своей собственной речевой структуры, жанр светских слухов с легкостью мимикрирует под любую типовую жанровую структуру, присущую массмедийному дискурсу. Границы исследуемого жанра столь проницаемы, что простираются от информационных форм, представленных событийной заметкой и новостной статьей до портретного или проблемного очерка (human interest stories, investigative features) - форм, присущих группе features. В коммуникативное поле жанра светских медиаслухов также легко вписывается и такая форма вторичного массмедийного жанра, как анекдот, что привносит в их жанровую специфику характеристики ироничного дискурса и способствует реализации функций эмоционального воздействия и оценки. В целом все задействованные типовые жанровые структуры «работают» на доминантную целеустановку - развлечение адресата. 
Таким образом, речевая специфика медиаслухов о селебрити заключается не в наличии собственной речевой структуры (она вариативна), а в тематической и содержательной одноплановости подобных дискурсивных практик, продиктованной их общей коммуникативной целеустановкой - показать красивую, материально обеспеченную и потому привлекательную жизнь. При этом исходный принцип такого «показа» заключается в том, что в центре этой красивой жизни стоит человек, обладающий высоким социальным статусом, имеющий успешную карьеру и являющийся публичной, известной личностью. Содержательная однотипность, инвариантность медиаслухов достигается посредством эксплуатации целого арсенала различных текстовых ресурсов, помогающих автору внушить адресату, что представленные им сведения обладают высокой информативной ценностью при явной тривиальности и сомнительности в плане достоверности. Соответственно, организация содержательной составляющей задействованных дискурсивных практик заключается в подтасовке, «игре», «жонглировании» реальными фактами и фактоидами, под которыми кроются неверифицируемые сведения, основанные на «показаниях» анонимных источников, вербализуемых различными эвиденциальными маркерами слухов, и обильно подкрепленные различными формами цитаций. Оказываются задействованными самые разнообразные средства доказательной базы: перекрестные ссылки на другие медийные источники, многочисленные цитирования в разнообразных вариантах речи (прямой, косвенной, несобственно-прямой, причем в объемах, варьируемых от одного слова до СФЕ). Попытки поднять верификативную планку при передаче неэвидентных сведений дополняются апелляцией к мнению «экспертов» из самых разных сфер и рангов, показаниям «свидетелей», «наблюдателей», «представителей» и пр. Обильно используемые эпистемические языковые маркеры выступают еще одним суггестивно-манипулятивным средством, реализующим функцию воздействия исследуемых текстов убеждения адресата в достоверности, правдивости раскрываемой журналистом информации. А журналистские формы информационно-новостной и публицистической категорий - заметка, статья, очерк и пр., в которую облекаются текстовые конкретизации жанра, также по сути становятся способом камуфлирования неподтвержденной «слуховой» информации, приемом маскировки под нейтральную цель - информирование.

Резюмируя, отметим, что в результате возникает текстовый стандарт, в котором воспроизводится конкретная модель типичной речевой ситуации, созданию и раскрытию которой подчинен исследуемый жанр, - это рассказ (информирование) о произошедшем событии или сложившейся ситуации из жизни и мира успешных и знаменитых, претендующий на исключительность и достоверность, но в реальности обладающий признаками неверифицированных сведений. В связи с этим можно утверждать существование особого дискурса неэвидентного типа, устойчиво сформированного в рамках многофункционального коммуникативного пространства массмедиа. 


\section{6. Заключение}

Тематическая прогрессия, созданная в рамках текстовых представителей жанра медийных светских слухов, с одной стороны, и их макроструктура, охватывающая широкий диапазон классических журналистских форм и структур вторичных медийных жанров, с другой, свидетельствуют о том, что дискурсивные практики, относящиеся к данной текстотипологической модели, могут быть причислены к категории гибридных образований, четко проявляющих черты полидискурсивности. Учитывая, что дискурс является языковым коррелятом той или иной социальной практики, а тексты - репрезентантами соответствующей дискурсивной формации, структурно-композиционный компонент в исследуемых текстах выступает как одно из специфических средств конструирования особого типа социальной реальности, связанной с жизнью и культурой селебрити.

(C) С.В. Иванова, Г.Ш. Хакимова, 2020
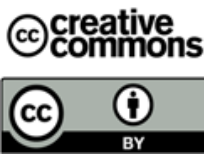

This work is licensed under a Creative Commons Attribution 4.0 International License https://creativecommons.org/licenses/by/4.0/

\section{СПИСОК ЛИТЕРАТУРЫ / REFERENCES}

Бахтин М.М. Проблема речевых жанров // Эстетика словесного творчества. М.: Искусство, 1979. С. 237-280. [Bakhtin, Mikhail M. 1986. Problema rechevykh zhanrov (The problem of speech genres). Aesthetics of verbal creativity. Moscow: Iskusstvo, 237-280. (In Russ.)].

Войтак М. О жанрах речи и их публицистических/печатных конкретизациях // Медиалингвистика. Вып. 3. Речевые жанры в массмедиа / по ред. Л.Р. Дускаевой. СПб.: СПбГУ, 2014. С. 9-13. [Voitak, Mariya. 2014. O zhanrakh rechi i ikh publitsisticheskikh/pechatnykh konkretizatsiyakh (On speech genres and their journalistic/printed representations). In Liliya Duskaeva (eds.), Medialinguistics. Mass media speech genres 3. 9-13. (In Russ.)].

Ван Дейк Т.А. Язык. Познание. Коммуникация: Пер. с англ. М.: Прогресс, 1989. 312 с. [Teun A. van Dijk. 1989. Language. Cognition. Communication. Moscow: Progress Publ. (In Russ.)].

Дементьев В.В. Теория речевых жанров. М.: Знак, 2010. 600 с. [Dement'ev, Vadim. 2010. Teoriya rechevykh zhanrov (The theory of speech genres). Moscow: Znak. (In Russ.)].

Добросклонская Т.Г. Вопросы изучения медиатекстов: Опыт исследования современной английской медиаречи. 4-е изд. М.: Красанд, 2013. 244 с. [Dobrosklonskaya, Tatiana G. 2013. Voprosy izucheniya mediatekstov: Opyt issledovaniya sovremennoi angliiskoi mediarechi. (Studying media texts: Experience in the study of modern English media speech). Moscow: Krasand. (In Russ.)].

Добросклонская Т.Г. Типологическое описание медиатекстов в системе медиалингвистики // Медиалингвистика. Вып. 3. Речевые жанры в массмедиа / под ред. Л.Р. Дускаевой. СПб.: СПбГУ, 2014. С. 17-21. [Dobrosklonskaya, Tatiana G. 2014. 
Tipologicheskoe opisanie mediatekstov $\mathrm{v}$ sisteme medialingvistiki (Typological description of media texts in the system of medialinguistics). In Liliya Duskaeva (eds.), Medialinguistics. Mass media speech genres 3. 17-21. (In Russ.)].

Дубин Б.В., Толстых А.В. Слухи как социально-психологический феномен // Вопросы психологии. 1993. № 3. С. 77-81. [Dubin, Boris V. \& Aleksandr V. Tolstykh. 1993. Slukhi kak sotsial'no-psikhologicheskii fenomen (Rumours as a social and psychological phenomenon). Voprosy Psychologii 3. 77-81. (In Russ.)].

Дускаева Л.Р. Интенциональность медиаречи: онтология и структура // Медиатекст как полиинтенциональная система: сборник статей / под ред. Л.Р. Дускаевой, Н.С. Цветовой. СПб., 2012. С. 10-17. [Duskaeva, Liliya R. 2012. Intentsional'nost' mediarechi: ontologiya i struktura (Media speech intentionality: ontology and structure). In Liliya Duskaeva \& Natalia Tsvetova (eds.), Mediatekst kak poliintentsional'naya sistema (Media text as a polyintentional system) 10-17. (In Russ.)].

Земская Е.А. Городская устная речь и задачи её изучения // Разновидности городской устной речи. М.: Наука, 1988. С. 5-44. [Zemskaya, Elena A. 1988. Gorodskaya ustnaya rech' i zadachi ee izucheniya (Perspectives of urban oral speech studying). Types of urban oral speech, 5-44. (In Russ.)].

Иванова С.В. Актовая речь как гибридная полидискурсивная практика // Вестник Российского университета дружбы народов. Серия: Лингвистика. 2017. Т. 21. № 1. C. 141-160. [Ivanova, Svetlana V. 2017. Commencement Speech as a Hybrid Polydiscursive Practice. Russian Journal of Linguistics 21 (1), 141-160. (In Russ.)]. DOI: $10.22363 / 2312-9182-2017-21-1-141-160$.

Карасик В.И. Языковой круг: личность, концепты, дискурс. М.: Гнозис, 2004. 390 с. [Karasik, Vladimir I. 2004. Yazykovoi krug: lichnost', kontsepty, diskurs (Language circle: personality, concepts, discourse). Moscow: Gnozis. (In Russ.)].

Ким М.Н. Новостная журналистика. Базовый курс: учебник. СПб.: Изд-во Михайлова B.A., 2005. 352 c. [Kim, Maksim N. 2005. Novostnaya zhurnalistika (Broadcast journalism). Basic course: Textbook. St. Petersburg: V.A. Mikhailov Publ. (In Russ.)].

Коньков В.И. Принципы классификации газетных жанров: острова стабильности // Медиалингвистика. Вып. 3. Речевые жанры в массмедиа / по ред. Л.Р. Дускаевой. СПб.: СПбГУ, 2014. С. 32-35. [Kon'kov, Vladimir I. 2014. Printsipy klassifikatsii gazetnykh zhanrov: ostrova stabil'nosti (Journalist genres classification principles: stability islands). In Liliya Duskaeva (eds.), Medialinguistics. Mass media speech genres 3. 32-35. (In Russ.)].

Корнилова Н.А. Антиномия фатических и информативных РЖ в массмедиа // Медиалингвистика. Вып. 3. Речевые жанры в массмедиа / по ред. Л.Р. Дускаевой. СПб.: СПбГУ, 2014. С. 55-59. [Kornilova, Natalia A. 2014. Antinomiya faticheskikh i informativnykh RZh v massmedia (Antinomy of phatic and informative speech genres in mass media). In Liliya Duskaeva (eds.), Medialinguistics. Mass media speech genres 3. 55-59. (In Russ.)].

Куликов Е.М. Слухи как элемент Интернет-пространства в условиях информационного общества // Теория и практика общественного развития. 2011. № 1. С. 86-88. [Kulikov, Evgeniy M. 2011. Slukhi kak element Internet-prostranstva v usloviyakh informatsionnogo obshchestva (Rumours as an element of web space in conditions of information society). Teoriya $i$ praktika obshchestvennogo razvitiya 1 . 86-88. (In Russ.)]. DOI: 0421100093\0019.

Куликов Е.М. Слухи в информационно-коммуникационной среде общества начала XXI в.: концептуальные основы социологического анализа // Вестник Краснодарского университета МВД России. 2014. № 3 (25). С. 90-93. [Kulikov, Evgeniy M. 2014. Rumors in the information-communication environment of the society of the 
beginning of the XXI century: the conceptual bases of the sociological analysis. Bulletin of Krasnodar University of Russian MIA 3 (25). 90 - 93. (In Russ.)].

Лаптева О.А. Живая русская речь с телеэкрана: разговорный пласт телевизионной речи в нормативном аспекте. 7-е изд. М.: Ленанд, 2015. 520 с. [Lapteva, Olga A. 2015. Zhivaya russkaya rech's teleekrana: razgovornyi plast televizionnoi rechi v normativnom aspekte (TV broadcasting colloquial Russian language speech in the normative aspect). 7th edn. Moscow: Lenand. (In Russ.)].

Лесная М.В. Популярная пресса на британском медиарынке // Вестник Адыгейского государственного университета. Серия 2: Филология и искусствоведение. Вып. 2. Майкоп, 2009. С. 65-67. [Lesnaya, Marina V. 2009. Populyarnaya pressa na britanskom mediarynke (Popular press on the British media market). The Bulletin of the Adyghe State University, the series "Philology and the Arts" 2. 65-67. (In Russ.)].

Луман Н. Реальность массмедиа / пер. с нем. А. Ю. Антоновского. М.: Праксис, 2005. 256 c. [Luman, Niklas. 2005. The reality of mass media. Moscow: Praksis. (In Russ.)].

Майдурова О.Ф. Информационные жанры в региональных новостных телепрограммах: актуальные тенденции. СПб.: СПбГУ, 2011. [Maidurova, Olga F. 2011. Informatsionnye zhanry $v$ regional'nykh novostnykh tele-programmakh: aktual'nye tendentsii (Information genres in local newscasts: essential trends). St. Petersburg: St. Petersburg State University Publ. (In Russ.)].

Мальцева Р.И., Лесная М.В. Новые концепции печатных СМИ // Телевидение, печать, Интернет: концепции, аксиология. Краснодар: Кубанский госуниверситет, 2008. C. 44-53. [Mal'tseva, Raisa I. \& Marina V. Lesnaya. 2008. Novye kontseptsii pechatnykh SMI (New conceptions of printed media). Televidenie, pechat', Internet: kontseptsii, aksiologiya (TV, press, Internet: conceptions, axiology), 44-53. Krasnodar: Kuban State University Publ. (In Russ.)].

Осетрова Е.В. Слухи в парадигме лингвистической генристики // Жанры речи. 2015. № 2 (12). C. 80 - 89. [Osetrova, Elena V. 2015. Rumours in the paradigm of linguistic genristics. Speech genres 2 (12), 80-89. (In Russ.)].

Панченко Н.Н. Сплетни как жанр бытового общения // Жанры речи. 2007. № 5. C. 224-232. [Panchenko, Nadezhda N. 2007. Spletni kak zhanr bytovogo obshcheniya (Gossip as a genre of social interaction). Speech genres 5. 224-232. (In Russ.)].

Понтон Д., Ларина Т.В. Дискурс-анализ в 21 веке: теория и практика (II) // Вестник Рос-сийского университета дружбы народов. Серия: Лингвистика. 2017. Т. 21. № 1. C. 7-21. [Ponton, Douglas. \& Tatiana V. Larina. 2017. Discourse Analysis in the 21st Century: Theory and Practice (II). Russian Journal of Linguistics 21 (1). 7-21. DOI: 10.22363/2312_9182_2017_21_1_7_21.

Рабенко Т.Г. Сплетня: юмористический профиль жанра (на материале рассказа А. Аверченко «Сплетня») // Известия Саратовского университета. Нов. сер. Сер. Филология. Журналистика. 2013. Т. 13. Вып. 3. С. 45-50. [Rabenko, Tatiana G. 2013. Gossip: Humorous Genre Type (on the Material of the story by A. Averchenko «Gossip». Izvestiya of Saratov University. New Series. Series: Philology. Journalism 13 (3). 45-50. (In Russ.)].

Сазонов Е. Феномен «желтой прессы» [Электронный ресурс] // Научно-культурологический журнал «Relga». 2005. № 7 (109). URL: http://www.relga.ru/Environ/ WebObjects/tguwww.woa/wa/Main?textid=497\&level1=main\&level2=articles (дата обращения: 25.02.2018). [Sazonov, Evgeniy. 2005. Fenomen «zheltoi pressy» (The phenomenon of yellow press). Relga 7 (109). Retrieved from: http://www.relga.ru/ Environ/WebObjects/tguwww.woa/wa/Main?textid=497\&levell=main\&level. (Accessed 25 February 2018). (In Russ.)]. 
Тертычный А.А. Жанры периодической печати. М.: Аспект Пресс, 2000. 158 с. [Tertychnyi, Aleksandr A. 2000. Zhanry periodicheskoi pechati (Genres in the periodical press). Moscow: Aspekt Press. (In Russ.)].

Тертычный А.А. Слухами полнятся СМИ... // Журналист. 2003. № 11. С. 73-75. [Tertychnyi, Aleksandr A. 2003. Slukhami polnyatsya SMI (Mass media are full of rumours). Journalist 11. 73-75. (In Russ.)].

Тертычный А.А. Перспективы развития жанровой системы СМИ России // Журналистика и медиаобразование-2010: Сб. тр. IV Междунар. науч.-практ. конф. (Белгород, 22-24 сент. 2010 г.) / под ред. А.П. Короченского, М.Ю. Казак. Белгород: Изд-во БелГУ, 2010. С. 51-57. [Tertychnyi, Aleksandr A. 2010. Perspektivy razvitiya zhanrovoi sistemy SMI Rossii (The development potential of the Russian mass media genre system). In Aleksandr Korochenskii \& Aleksandr Kazak (eds.), Journalism and Media Education-2010, 51-57. Belgorod: BSU Publishing. (In Russ.)].

Хакимова Г.Ш. Концепт «слух» в фокусе лексикографического анализа. Ч. 1 // Вестник ЮУрГУ. Серия «Лингвистика». 2016а. Том 13. № 2. С. 29-36. [Khakimova, Gulnar Sch. 2016a. Kontsept "slukh" v fokuse leksikograficheskogo analiza (Chast' 1) [Concept "rumour" in terms of lexicographic analysis. Part 1. Vestnik YuUrGU. Seriya «Lingvistika» 13 (2). 29-36. (in Russ.)]. DOI: 10.14529/ling160206.

Хакимова Г.Ш. Концепт «слух» в фокусе лексикографического анализа. Ч. 2 // Вестник ЮУрГУ. Серия «Лингвистика». 2016б. Т. 13. № 3. С. 38-46. [Khakimova, Gulnar Sch. 2016b. Kontsept "slukh" v fokuse leksikograficheskogo analiza (Chast' 2) [Concept "rumour" in terms of lexicographic analysis. Part 2. Vestnik YuUrGU. Seriya «Lingvistika» 13 (3). 38 - 46. (in Russ.)]. DOI: 10.14529/ling160307.

Шмелева Т.В. Современная медиапрактика с позиций теории речевых актов // Медиалингвистика. Вып. 3. Речевые жанры в массмедиа / под ред. Л.Р. Дускаевой. - СПб.: СПбГУ, 2014. С. 51-55. [Shmeleva, Tatiana V. 2014. Sovremennaya mediapraktika s pozitsii teorii rechevykh aktov (Contemporary media practice from the perspective of the speech act theory). In Liliya Duskaeva (eds.), Medialinguistics. Mass media speech genres 3. 51-55. (In Russ.)].

Boyd-Barrett, Oliver. 1977. Media imperialism: towards an international framework for the analysis of media systems. In Michael Gurevitch, James Curran \& Janet Woollacott (eds.), Mass Communication and Society, 116-135. London: Edward Arnold.

Demerath, Loren, \& Andrey V. Korotayev. 2015. The Importance of Gossip Across Societies: Correlations with Institutionalization. Cross-Cultural Research 49 (3). 297-314. DOI: $10.1177 / 1069311454383$.

Dubois, David, Derek D. Rucker, \& Zakary L. Tormala. 2011. From rumors to facts, and facts to rumors: The role of certainty decay in consumer communications. Journal of Marketing Research 48 (6). 1020-1032. DOI: 10.1509/jmr.09.0018.

Gelfert, Alex. 2012. Coverage-Reliability, Epistemic Dependence, and the Problem of RumourBased Belief. Philosophia 41 (3). 763-786. DOI: 10.1007/s11406-012-9408-z.

Levin, Jack \& Allan J. Kimmel. 1977. Gossip Columns: Media Small Talk. Journal of Communication, 169-175. Winter.

Walls, Jeannette. 2001. Dish: How Gossip Became the News and the News Became Just Another Show. New York: HarperCollins Publishers.

\section{Словари и интернет-ресурсы / Dictionaries and Internet Resources}

Chambers, Deborah. April 2009. The flaunting of fertility: popular media representations of maternal. Retrieved from: http://atelim.com/the-flaunting-of-fertility-popular-mediarepresentations-of-th.html. 
Mole, Tom. Nov. 2004. Hypertrophic Celebrity. M/C Journal 7 (5). Retrieved from: http://journal.media-culture.org.au/0411/08-mole.php.

Collins English Dictionary. URL: http://www.collinsdictionary.com/dictionary/english. Retrieved from: http://www.collinsdictionary.com/dictionary/english. (Accessed 03April 2018).

Webster's New World College Dictionary. URL: http://websters.yourdictionary.com/ Retrieved from: http://websters.yourdictionary.com. (Accessed 12 March 2018).

\section{Примечания}

Webster's - Webster's New World College Dictionary, Collins — Collins English Dictionary

Article history:

Received: 27 January 2020

Revised: 18 March 2020

Accepted: 25 March 2020

\section{История статьи:}

Дата поступления в редакцию: 27 января 2020

Дата принятия к печати: 25 марта 2020

Сведения об авторах:

СВЕТЛАНА ВИКТОРОВНА ИВАНОВА - доктор филологических наук, професcop, заведующий кафедрой английской филологии Ленинградского государственного университета им. А.С. Пушкина, член редколлегии журнала Russian Journal of Linguistics. Сфера научных интересов: медиалингвистика, лингвокультурология, дискурс-анализ текстов СМИ, политическая лингвистика, теория текста.

\section{Контактная информация:}

Ленинградский государственный университет имени А.С. Пушкина

196605, Россия, г. Санкт-Петербург, Пушкин, Петербургское шоссе, д. 10

e-mail: svet_victoria@mail.ru

ORCID ID: 0000-0002-0127-9934

Scopus Author ID: 57194882590

ГУЛЬНАРА ШАРИФУЛЛОВНА ХАКИМОВА — кандидат филологических наук, доцент, доцент кафедры социально-правовых и гуманитарных наук филиала ЮжноУральского государственного университета в г. Златоусте. Сфера научных интересов: гендерная лингвистика, лингвокультурология, когнитивная лингвистика, дискурс-анализ текстов СМИ, теория текста, румурология.

\section{Контактная информация:}

филиал Южно-Уральского государственного университета в г. Златоусте

Россия, 456209, Челябинская область, г. Златоуст, ул. Тургенева, д. 16

e-mail: gkhakimova@yandex.ru

\section{Bionotes:}

SVETLANA V. IVANOVA is Dr. of Philology, Full Professor, Head of English Philology Department at Pushkin Leningrad State University. Research Interests: Media Linguistics, Cultural Linguistics, Discourse Analysis of Mass Media, Political Linguistics. 


\section{Contact information:}

Pushkin Leningrad State University

10, Peterburgskoye shosse, Saint-Petersburg, 196605, Russia

e-mail: svet_victoria@mail.ru

ORCID ID: 0000-0002-0127-9934

Scopus Author ID: 57194882590

GULNARA SH. KHAKIMOVA is Dr. of Philology, Associate Professor, Associate Professor of Socio-Law and Humanity Sciences Department at South Ural State University, Branch in Zlatoust. Research Interests: Gender Studies, Cultural Linguistics, Cognitive Linguistics, Discourse Analysis of Mass Media, Rumourology.

\section{Contact information:}

South Ural State University Branch in Zlatoust

16 Turgenev Str., Zlatoust, Chelyabinsk region, 456209, Russia

e-mail: gkhakimova@yandex.ru 